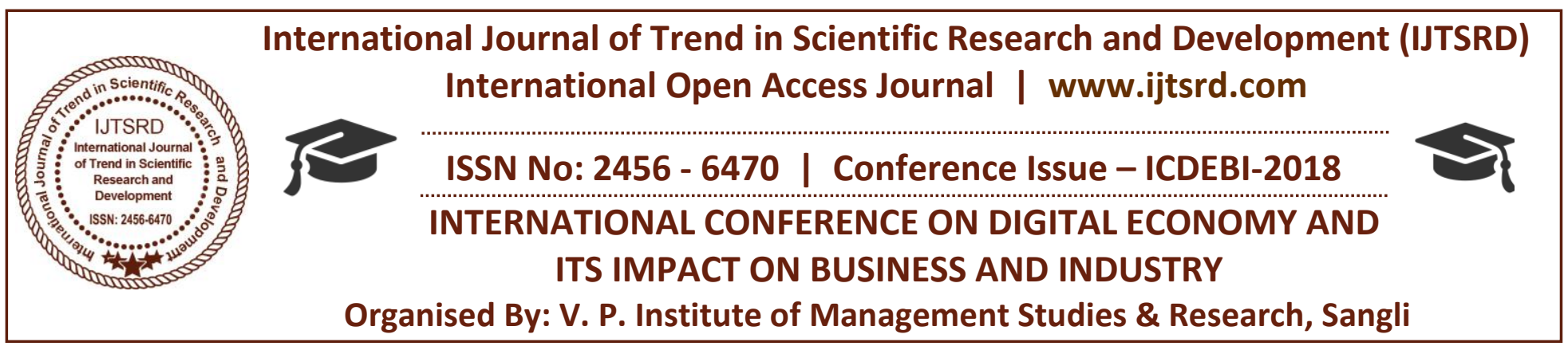

\title{
The Trend of Digitalization in Marketing and its Impact on the Customers
}

\author{
Dr. Anand Patil \\ Associate Professor, School of Business Studies and Social Sciences CHRIST (Deemed to be University), \\ BGR Campus, Bannerghatta Main Road, Hulimavu, Bangalore, Karnataka, India
}

\section{ABSTRACT}

The firms and the Marketers are faced with new opportunities and challenges within this digitalized age. The vital objective of digital marketing is to attract customers and allowing them to interact with the company's brand through electronic/digital media. This article focuses on the importance of digital marketing for both the consumers and marketers. We have examined the effects of digital marketing on the consumer's buying decision making and Its impact on firms' sales. Adding up to this, distinguish between traditional marketing and digital marketing are presented in this paper. This study has described various forms of digital marketing, its effectiveness and the impact it has on the firm's sales. The examined sample consists of reports and analysis based on the online survey conducted by us to prove the effectiveness and efficiency of digital marketing. Collected data has been analyzed with the help of different statistical techniques and tools. The results have also stated that the consumers have a positive view towards digital communication while checking out a product, they get affected from other customer's comments and reviews and they do express their postpurchase experiences over the digital/ electronic platforms. 'Website' is the most used digital medium of communication while purchasing a product or service followed by 'smart phones' and 'social networking sites'. Each stage of consumer's buying decision making procedure starting from 'need identification' to 'post-purchase' experience sharing is significantly affected by digital marketing communication media with the 'evaluation' being the most important stage. However, this study has also established that although the customers encourage the usage of digital mediums throughout their buying decision-making journey, still they do not order many products online very often.

KEYWORD: Digital Marketing, objectives, research results, Promotion, Effectiveness, mass Customer Reach, Impact, comparative quantifiable data, statistical data, problems and solutions.

\subsection{INTRODUCTION}

Digital marketing is a type of marketing which is being largely used to promote the products and services to reach mass consumers by using digital channels of communication. The utilization of the electronic means of media by the marketers for promoting their products or services in the market is the main basis of Digital marketing. Digital marketing stretches beyond the internet/ online marketing including sources that do not require use of Internet. It involves mobiles/ cells (for both SMS and MMS), search engine marketing, visual advertising, social media marketing, and various other forms of digital/ electronic media.

Through electronic/digital media, consumers are able access to any information at any time and any place whenever they want. With the emergence of digital media, consumers do not just depend on the company's brand says but also, they follow the friends, media, association, peers, etc., as well. Digital marketing is a broader term that refers to the various kinds of promotional tools and techniques involved to reach the customers via digital methods of technologies. 
This is the current emerging trend in "Modern Marketing". Generally, crucial advantage of digital marketing is that it can enable companies to increase the reach and reduce the costs (Watson et al. 2002; Sheth \& Sharma 2005). According to Chaffey (2011), social media marketing includes "encouraging the customer's communications and reviews on company's own websites or through its social media presence". Giese and Gote (2000) finds out that customer information satisfaction (CIS) for the electronic or digital marketing can be framed as a total of effective responses of different volume that follows the consumption and is geared by focal aspects of the sales activities, websites (information systems), digital products/services, after-sales service, customer support and company culture. Waghmare (2012) had pointed out that large number of countries in Asia is taking the benefits of the e-commerce platforms through opening up, which is very essential for promoting competition and the diffusion of the Internet technologies. Zia and Manish (2012) found out that at present, buyers in metropolitan cities in India are being driven by the e-commerce: these consumers are buying consumer electronics, booking travels and books online. Although spending of time of per online shopper remains low, approximately $59 \%$ online consumers in the metropolitan India already make purchases through online websites in at least once in a month.

\subsection{Objectives of the study :}

i. To know the different elements of digital marketing.

ii. To know the global use of social media sites and devices

iii. To know the impact of digitalization on the customers.

iv. To know the impact of digitalization on marketing.

\section{Research Design:}

Source of Data: Primary and Secondary Data

Primary Data: Questionnaire.

Secondary Data: Journals, Websites

Sample Size: 100 Customers

Tools Used for Analysis: Tables and Graphs

\section{Data Analysis and Interpretation:}

4.1 Elements of digital marketing:

There are various elements of digital marketing but the recent one are search engine optimization(SEO) and search engine marketing (SEM). The rest of the elements were done before. I would like to explain the various elements and how they are important to the digitalization of marketing.

\section{Search Engine Optimization(SEO) :}

used naturally or organically for the search results in Google or, sometimes seen used with Yahoo Bing and any other search engine

\section{Search Engine Marketing(SEM):}

used to drive traffic to any business, or basically from the paid efforts. According any business sturucture, a firm would choose pay-per-click that is PPC and costper-click known as CPC and the last one cost-perthousand impressions CPM model.

\section{Content creation:}

The content creation it is presented in various methods in different formats. These formats are blogs, white papers, banners, inforgraphics, how-to-guids, videos, webinars, news and updates, images podcasts, case studies, e- books, question answer articles mainly used by various students for different study purposes and the last is through the social media sites.

\section{Social Media Marketing(SMM):}

The various digital marketing elements here the social media marketing is another element that is used for driving the traffic to your official sites or the business through the social media sites. The various sites like facebook, instagram, twitter, pinterest, google+, linkedin are used to share the information on the recent trends of marketing. So we can say that the above mentioned sites are maily used to share the important content through these sites to let the readers know about the recent marketing. Therefor the content you share will be seen and if it is proper it will be liked.

\section{Digital Display Advertising:}

The digital display advertising is seen as a subset of the Search engine Marketing. When it comes to marketing a business will be seen using various methods which should be effective and necessary for dislplaying different advertinging formats in order to target the right and potential audientce. The kinds of advertisments which are displayed and shown to the customers should be attractive and should instinctly catch the eyes of the audience so that they will be intrested in a perticular product that is being marketed. 
VI. Remarketing or Retargeting:

We need to understand that in business marketing the stratagies like remarketing and retargeting are very essential for targeting the right audience or the customers.

\section{Mobile Marketing:}

The mobile marketing is another source and ways of advertising your porducts. Therefor a business may choose to advertise their new innovations through mobile.

\section{Interactive marketing:}

It is important to note that any new stategy you come up with for introducing to the potential customes, first you must make sure that your advertising stategy is properly made in order to keep the customers engaged in the conversation.

\section{Viral marketing:}

Accoding to researchers it is known that viral marketing is good strategy and essential for spreading unique content through online. This is due to the proper content shared and it is liked by various readers immensely.

\section{Email marketing:}

The email marketing is when you decide and find a way to send your message through email to various listed customers who are potential, therefor the strategy is called as the Email marketing. In order to maintain a proper listed customers it is best to use the effective email marketing software.

\section{Affiliate marketing:}

Affiliate marketing is one of them where it is the arrangement made on online retailers. Theses retailers are to pay commission website either for traffic or the sales which are generated from its referrals.

\section{Digital media planning and buying:}

This is where the media agency researched for a proper strategy framework and is therefor called as the digital media planning. This is the process through which the sales or the conversions are launched with a new brand or the ability to promote an established brand that already exists.

\section{Web analytics:}

Along with all the above elements to digitalization in marketing sector, web analystics is another essential and is important for any digital marketing. It is known that web analystics plays a very important role in the marketing and helps you in collecting, measuring, understanding, planning, analysing, reporting and predicting the necessary web activities for yur business.

\subsection{Comparative quantifiable percentage in digitalization marketing:}

Here is the comparison of percentages in digitalization marketing starting from the years of 2001 to 2017. As researches have been made on how the information and communication technology known as ICT in knowing the impact on digitalization marketing across the globe. Here I will be showing how much of digital marketing is used by people with various social media channels and platforms. In the graph below, will help to understand the usage of digital marketing at various stages and through what type of technological platforms varying from different years.

Global use of social media sites and devices 2001-2017:

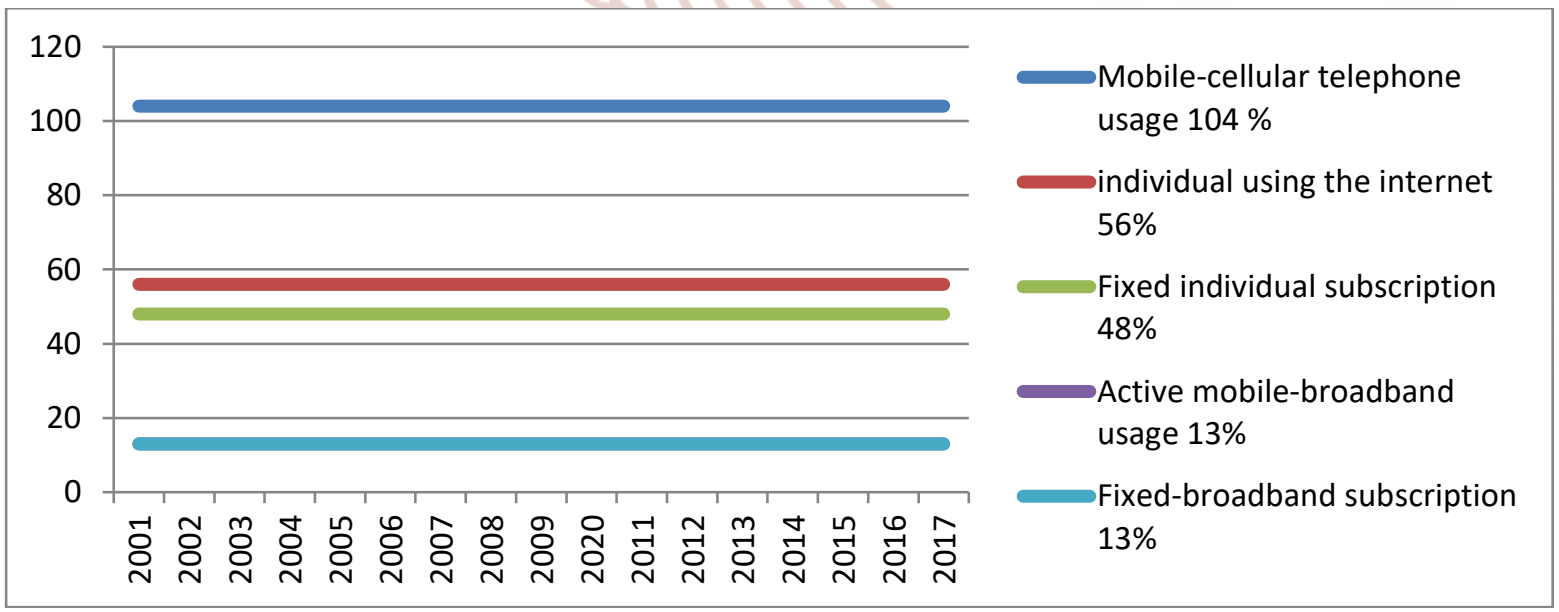

Source: - Global Web Index: 
The different types of social media sites and various devices used as a technological platform. The usage of various social media platforms for digital marketing to different channels is growing faster each year. This is with the help of the usage of internet, Face book, twitter, Instagram and others. This various channel has been making it easier for the online purchasing of good. This has said as a global Web Index to be paid as a service giving insights on consumer usage of social network sites globally and different countries. But it is known that many businesses for digital marketing regularly feature very specific social media stats on although they stopped releasing reports on slide share to encourage purchase of their subscription product.

International telecommunication union known as (ITU) is considered to be global and that by every country's source with the biggest sample size for the big picture of digital device usage and along with the possible trends by continent. This also includes the usage of fixed and mobile broadband access by country per percentage of the people. This is latest release of comparative percentage on digital marketing across the globe starting from the end of 2016 that shows the growth opportunity for Internet access along with higher-speed Smartphone use across the world.

\subsection{Impact of Digital Marketing on Businesses:}

\section{Positive Impact}

$>$ Wide Variety of Easily Accessible Marketing Outlets:

The digital marketing provides a way as an opening to many new opportunities in business world. There are various types and ways of marketing that may be though social media, email campaigns, content marketing, Search Engine Optimization, banner ads, and many others. It is understood that all of these functions are to make it easier and to take care of online buying or shopping including making the process go smoother.

\section{More affordable Methods of Reaching a Wider Audience:}

When it comes to online buying many businesses make a basic understanding that advertising online is less expensive than print advertising and therefore more people see it that way. It is considered to be simple where hundreds or even thousands of people are able to reach respective sponsored posts on different social media sites. It may take say for example a hundred dollars to run a single print ad in a newspaper. After this a consideration is to be given to whether the target demographic of the people are even seeing the ad or are they able to see the ads.

Larger access to online advertisement: Most of the people are these days are always online and therefore this makes it easier for the marketing advertisements through various channels. People are always interested in knowing what types of products are available and are they affordable. The audience needs to have a basic understanding and knowledge of new products that are being launched. Nowadays days, people are able to get everything from news, weather, the gossip so on along with Bessie's latest affair, and even with groceries they purchase, with a simple method of few clicks of a mouse or swipes of a finger.

\section{Negative Impact:}

As much as we can see impacts on the digitalization marketing, there are also negative impacts whereas the benefits are easy to see but another important consideration we have to keep in mind is when you go digital with your marketing plan, it is known to be the negative impact of digital marketing. A question may arise in the minds of any business such as what could go wrong and through which type of digital marketing. As many things are being advertised where more people are viewing marketing content, there's always the fear were the receiving audiences may take the message in a wrong way or perceived in the wrong direction.

In the business world there are always negatives with any marketing strategy, but the impact of digital marketing on businesses is considered to be a positive one. This is with the possibility of access to a broader audience, digital marketing illuminates' businesses in ways that were once impossible. This helps by saving businesses time, money, and bringing in new customers like never before. 
International Journal of Trend in Scientific Research and Development (IJTSRD) ISSN: 2456-6470 | IF: 4.101

4.4. The data collected from the 100 respondents is analyzed and interpreted with the help of tables and

\subsection{Age:} graphs

\begin{tabular}{|c|c|}
\hline Age & No. Of People (responses) \\
\hline $18-25$ & 53 \\
\hline $25-30$ & 20 \\
\hline $31-40$ & 18 \\
\hline $41-50$ & 9 \\
\hline $51-55+$ & 8 \\
\hline
\end{tabular}

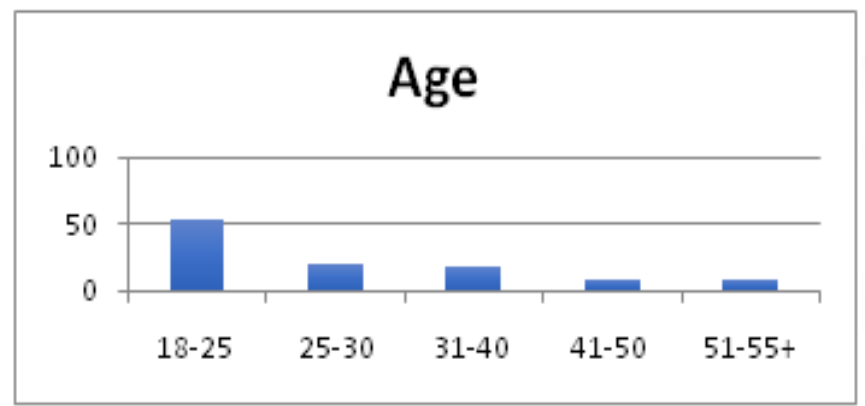

\section{Interpretation:}

The age groups that mostly prefer the digitalization in marketing were from 18-25 ages. As we can see from the above graph that the age group is mostly young audience and the responses we got for that is 53 members. So, we can say that when it comes to digital in marketing the main audience is the younger generation.

\subsection{Gender:}

\begin{tabular}{|c|c|c|}
\hline Particulars & $\begin{array}{c}\text { No. of } \\
\text { respondents }\end{array}$ & Percentage \\
\hline Female & 49 & 49 \\
\hline Male & 52 & In 52 ind \\
\hline
\end{tabular}

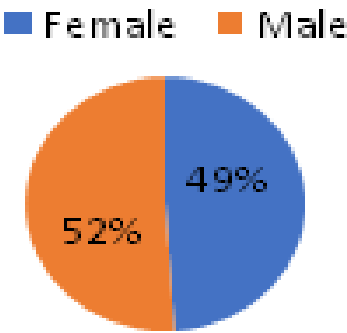

Interpretation:

According to this graph, it is proven that customers of both the gender either male or female both are equally involved in digital marketing procedure for buying Products through internet or online websites.

\subsection{Digital Marketing Experience:}

\begin{tabular}{|c|c|c|}
\hline Particulars & $\begin{array}{c}\text { No. of } \\
\text { respondents }\end{array}$ & Percentage \\
\hline Yes & 81 & 75.7 \\
\hline No & 26 & 24.3 \\
\hline
\end{tabular}

Do you have any experience in buying products through online websites? 07 responses

Interpretation:

According to this question, most of the respondents have agreed that they have prior buying experiences through online websites. This proves and digital marketing is taking place rapidly and is following the current trends of the markets and customers.

\subsection{Usage of Online Websites}

\begin{tabular}{|c|c|c|}
\hline Particulars & $\begin{array}{c}\text { No. of } \\
\text { respondents }\end{array}$ & Percentage \\
\hline Once in a week & 32 & 32 \\
\hline Once in a month & 33 & 33 \\
\hline Once in six months & 23 & 23 \\
\hline Once in a year & 13 & 12 \\
\hline
\end{tabular}

*If yes, how often do you use internet/online websites to buy products and services? 100 responses

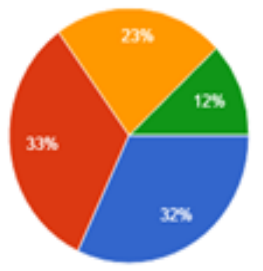


Interpretation:

This data shows that how frequent a respondent purchase product through online channels. According to this statistical data, around $32 \%$ of the total respondents buy products through digital medium almost on a weekly basis.

This proves that more or less the customers are well connected with digital marketing methods.

\subsection{Clear Display of Instructions:}

\begin{tabular}{|c|c|c|}
\hline Particulars & $\begin{array}{c}\text { No. of } \\
\text { respondents }\end{array}$ & Percentage \\
\hline Agree & 78 & 78 \\
\hline Disagree & 17 & 17 \\
\hline Neutral & 5 & 5 \\
\hline
\end{tabular}

The instructions displayed in the web while purchasing are clear 100 responses
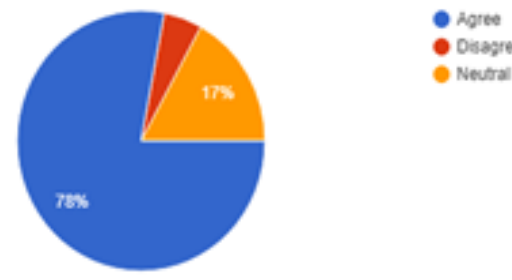

Osagren

- Neutal

Interpretation: Among the respondents $78 \%$ said the instructions were clearly displayed.

\subsection{Easy Navigation:}

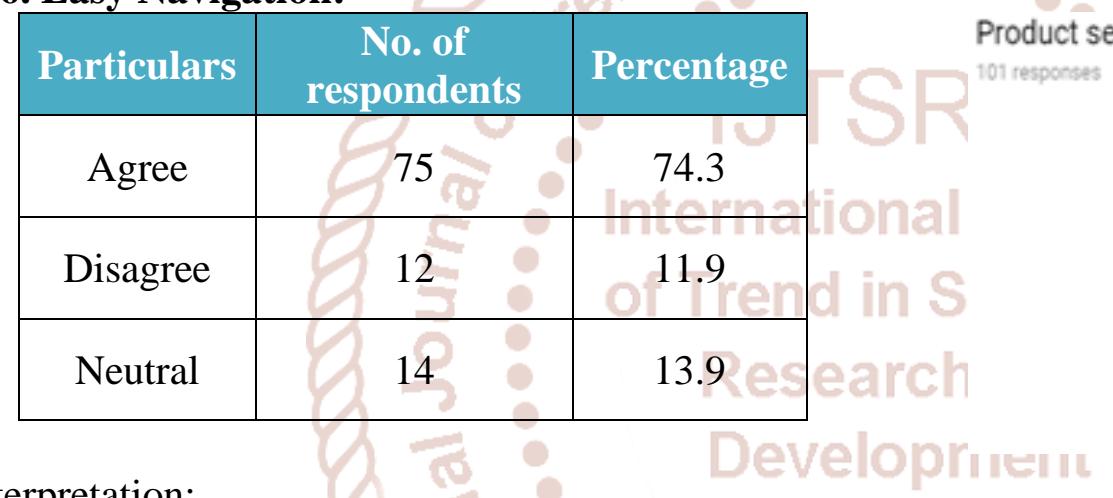

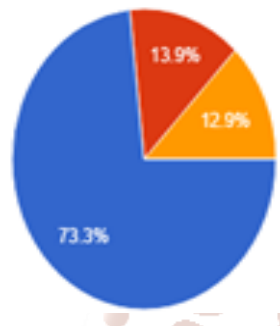

- Agree

- Disagree

- Nedtral

Interpretation:

According to this statistical data, it has been found that $74.3 \%$ of the total respondents are agreed that they find it easy to navigate via online website to buy products. It proves that digital marketing has simplified the process of searching of products through a common digital platform

\subsection{Easy Product Selection:}

\begin{tabular}{|c|c|c|}
\hline Particulars & $\begin{array}{c}\text { No. of } \\
\text { respondents }\end{array}$ & Percentage \\
\hline Agree & 74 & 73.3 \\
\hline Disagree & 14 & 13.9 \\
\hline Neutral & 13 & 12.9 \\
\hline
\end{tabular}

Product selection is easy and it has access to latest products 101 responses

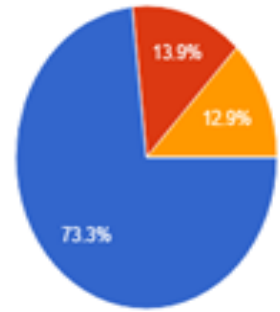

Agree Disagree Neutral

Interpretation:

According to this data, it is established that most of the respondents have agreed that the selection of products via online websites are relatively easier than that of other sources. This enhances the efficiency of digital marketing. 
International Journal of Trend in Scientific Research and Development (IJTSRD) ISSN: 2456-6470

4.8. Simple Payment Process:

\begin{tabular}{|c|c|c|}
\hline Particulars & $\begin{array}{c}\text { No. of } \\
\text { respondents }\end{array}$ & Percentage \\
\hline Agree & 78 & 77.2 \\
\hline Disagree & 13 & 12.9 \\
\hline Neutral & 10 & 9.9 \\
\hline
\end{tabular}

Payment Procedure is simple 101 responses

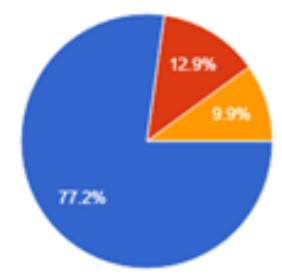

- Agree

- Disagree

- Nevtral

\section{Interpretation:}

This data gives the statistics of whether the online digital markets performs smoothly in terms of transactions or not. Here, most of the respondents have agreed that the online transactions are hassle free and safe. Whereas, very few are also disagreed with this fact.

\subsection{Reliability through Images: \\ Images of the product provides reliability}

\begin{tabular}{|c|c|c|}
\hline Particulars & $\begin{array}{c}\text { No. of } \\
\text { respondents }\end{array}$ & Percentage \\
\hline Agree & 50 & 49.5 \\
\hline Disagree & 24 & 23.8 \\
\hline Neutral & 27 & 26.7 \\
\hline
\end{tabular}
101 responses
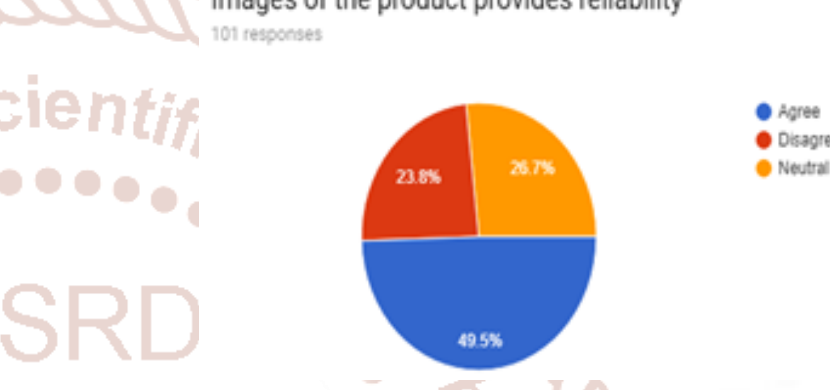

Neutral

Interpretation:

This data shows the reliability on images during online purchases. According to $49.5 \%$ respondents, the images shown are reliable and easy to indicate the actual product.

\subsection{Easy Complaint Registering:}

\begin{tabular}{|c|c|c|}
\hline Particulars & $\begin{array}{c}\text { No. of } \\
\text { respondents }\end{array}$ & Percentage \\
\hline Agree & 72 & $72 \mathrm{SN}$ \\
\hline Disagree & 12 & 12 \\
\hline Neutral & 16 & 16 \\
\hline
\end{tabular}

Interpretation:

This data produces information about the customer care services available while purchasing through online websites. This data shows that $72 \%$ of the respondents have agreed to this fact that availability of customer services, especially for registering complaints and approachable.

These are safe and secure and highly confidential.

\subsection{No Overcharging Via Card Payments:}

\begin{tabular}{|c|c|c|}
\hline Particulars & $\begin{array}{c}\text { No. of } \\
\text { respondents }\end{array}$ & Percentage \\
\hline Agree & 62 & 59 \\
\hline Disagree & 15 & 14.3 \\
\hline Neutral & 28 & 26.7 \\
\hline
\end{tabular}

Websites have contact details for registering complaints 100 responses

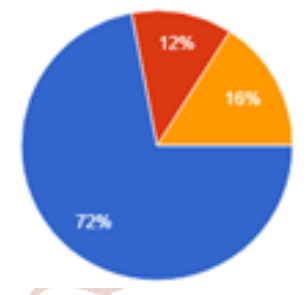

- Agree

- Desagres

Q Neutra

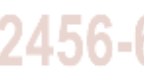


Interpretation:

This data gives a detailed view of whether the costs charged are affordable or not. In here, 59\% of the respondents have positively reacted towards the card payments and have agreed that the online sellers do not overcharge the debit or credit cards.

\subsection{Product Quality:}

\begin{tabular}{|c|c|c|}
\hline Responses & Percentage & Responses \\
\hline Neutral & $36 \%$ & Neutral \\
\hline Agree & $58 \%$ & Agree \\
\hline Disagree & $10 \%$ & Disagree \\
\hline
\end{tabular}

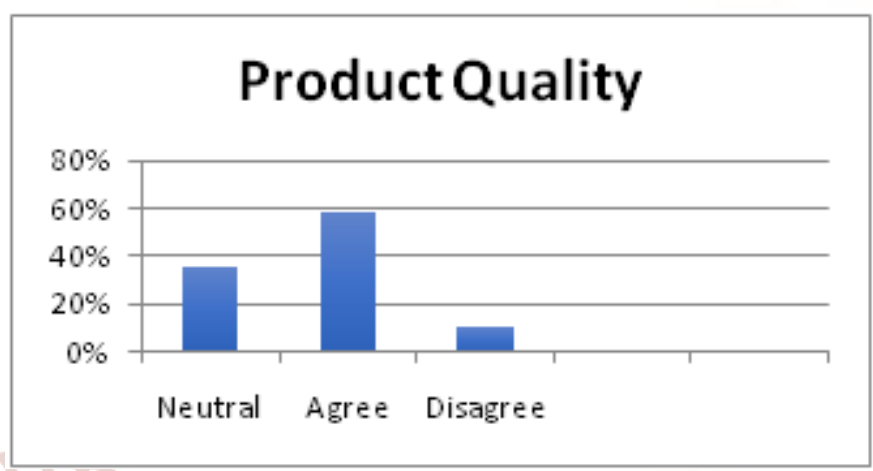

Interpretation:

The product quality here in the above graph is seen were most of the customers agree that the product condition is very good. The Graph shows that the number of people that choose agree is 58 members. Therefore it means the product quality is good when purchasing goods.

\subsection{Importance of social platform:}

\begin{tabular}{|c|c|c|}
\hline Responses & Percentage & Responses \\
\hline Agree & $79 \%$ & Agree \\
\hline Disagree & $6 \%$ & Disagree \\
\hline Neutral & $19 \%$ & Neutral \\
\hline
\end{tabular}

Social platform

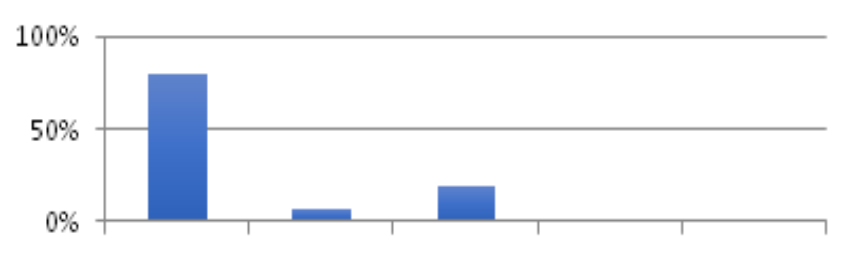

Neutral Agree Disagree

Interpretation:

The above graph shows that the importance of social platform that the customers prefer is neutral. Here the most of the audience which are our customers agreed that social media have influence and good impact on the purchase of products when it comes to digital marketing.

\subsection{Social Media Channel Used:}

\begin{tabular}{|c|c|c|}
\hline Sources & $\begin{array}{c}\text { No. Of People } \\
\text { (responses) }\end{array}$ & Sources \\
\hline Twitter & 12 & Twitter \\
\hline Facebook & 37 & Facebook \\
\hline Instagram & 28 & Instagram \\
\hline
\end{tabular}

\section{Social Media Channel}

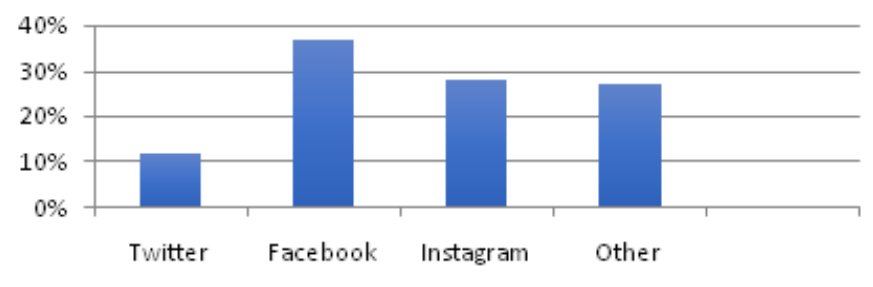

Interpretation:

As we did the survey to know the kind of social media channel that is used when it comes to purchasing or buying. The above graph shows that the customers mostly use Face book. This is also the platform were the new products are advertised as to attract the audience attention. 
4.15. Influence on Internet on customer satisfaction:

\begin{tabular}{|c|c|c|}
\hline Responses & $\begin{array}{c}\text { No. Of People } \\
\text { (Percentage) }\end{array}$ & Responses \\
\hline Yes & $64 \%$ & Yes \\
\hline No & $6 \%$ & No \\
\hline Maybe & $19 \%$ & Maybe \\
\hline
\end{tabular}

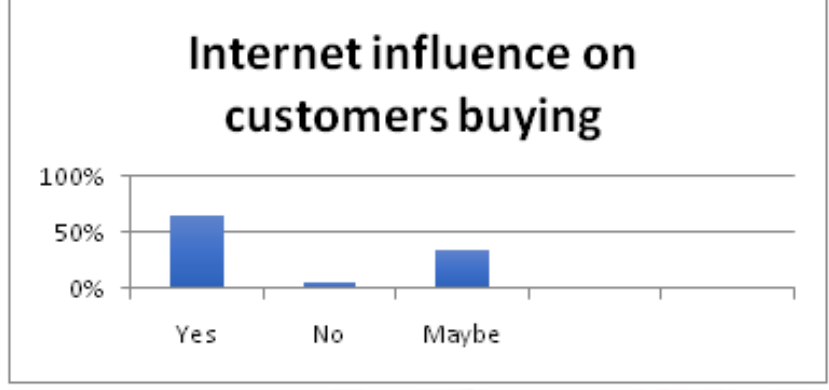

Interpretation:

When it comes to digital marketing internet plays a major role in allowing the customers to know about the products which are being launched newly. Therefor we can see that in the above diagram that audience has replied that internet influences the buying and purchasing products online.

4.16. Customer Satisfaction:

\begin{tabular}{|c|c|c|}
\hline Responses & $\begin{array}{c}\text { No. Of People } \\
\text { (Percentage) }\end{array}$ & Responses \\
\hline Agree & 61 & Agree \\
\hline Disagree & 9 & Disagree \\
\hline Neutral & 33 & Neutral \\
\hline
\end{tabular}

\section{Customer Satisfaction}

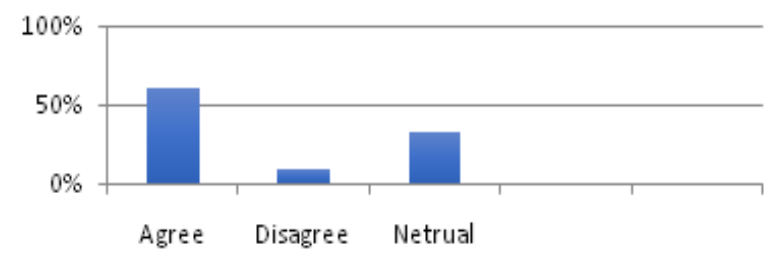

Interpretation:

When it comes to digital marketing it is important to know that whatever products are bought either online or directly will make the customers satisfied. Here we can see that the goods should have an impact on digitalization market for customer satisfaction. The above graph shows that most of the audiences have agreed and their satisfaction level is high.

\section{Problems and Solutions:}

\subsection{Making the most of a smaller budget:}

Here we can understand that one of the biggest digital marketing concerns for businesses is where one business is able to stand out from others against bigger competitors without equal digital marketing budget. When it comes to marketing in the business world, we do know that larger competitors can feel like they have an unfair advantage. Therefor he solutions given below are some of the best ways to level the playing field.

Solutions to this problem:

- SEGMENT YOUR AUDIENCE

- INVEST IN LOCAL

- GET SOCIAL-SPECIFIC

- USE PAID ADVERTISING ON SOCIAL MEDIA

- CONNECT WITH INFLUENCERS

\subsection{Clicks but No Conversions:}

Clicks but no conversions is another major problem when it comes to Healthy numbers of clicks attached to high conversion rate and therefore it considered to be one of the most common digital marketing problems that any businesses would face in the marketing world. In many cases it is seen that it can be extremely frustrating to spend the money for many clicks, but there is no improvement on the rate of sales Here are some of the best solutions mentioned in order problems to be solved for this classic and unfortunately timeless digital marketing problem.

$>$ Solutions to this problem:

- AUDIENCE ISSUES

- INEFFECTIVE LANDING PAGES

- MIXED MESSAGING

\subsection{Social Media aren't always flourishing:}

When it comes to digital marketing, in many cases it is seen that the social media has a reputation and is 
famously known for being quick, easy, and free engagement with your audience. In larger sense the practice that is put into can be a difficult for getting the right medium. Many businesses don't approach social media with the sophistication needed to see success. There for there are various solutions to these such problems and how it can help in the fluctuations of the social media.

$>$ Solutions to these problems:

- WATCH YOUR FREQUENCY

- OFFER SOMETHING

- ACTUALLY, BE SOCIAL

- CONNECT WITH HAPPY CUSTOMERS

\subsection{Tough Ranking Competition:}

As we known that the completion in any business is tough and its ranking can be seen either high or low as compared to other competitions. Here the search engine optimization also known as SEO and its competition can be challenging. When setting up your business deciding on your location and industry, one has to keep in mind that there could be thousands of competitors waiting to get on the same few spots on Google's front page. Therefore it is understood and seen making it worse and also there are dozens of finding the moving parts to SEO. This will help in figuring out how to stand out against the other tough competitions. Hence, we need to understand that this can be overwhelming. Here some of the solutions are given proven ways to compete with others when it comes to page ranking.

$>$ Solutions to this problem:

- Don' use SEO in the Same Way

- Don't Rank in the Same Place

- Focus on Customer Experience

\section{Findings}

1. Mobile Cellular usage is more than the individual internet usage and others.

2. Increasing scope for improving market share by digitalization

3. Fear of the receiving the message by the audiences in a different way.

4. There is a higher positive impact of digitalization on the customers.

\section{Suggestions and Conclusion:}

There is a need for optimum utilization of different means of digitalization. The negative impact of digitalization is to be converted in to fruitful business opportunity by convincing the customers and creating awareness. Digital and electronic channels in marketing have become an essential part of strategy of many companies. Nowadays, even for the small business owners there are very efficient and cheap ways to market her/his services and products. There are no boundaries in Digital marketing. Companies and organizations can make use of any electronic devices such as tablets, smart phones, televisions, laptops, digital billboards, game consoles, and media such as social media, videos, SEO (search engine optimization), content, Google+, e-mail and many more to accelerate promotion of the company itself as well as its products and services. Digital/electronic marketing may get more success if it takes into consideration the customer's needs as a top priority. Digital marketing results won't come without attempting, just like the way "Rome was not built in a day," without trial (and misinterpretation). The watchwords "test, evolve and learn" is a must to be kept at the heart and mind of all digital marketing companies and initiatives. Companies and organizations should put more efforts to create innovative and novel customer experiences and unique strategies for media to identify and catch up the best path for driving up and establishing digital marketing performance.

\section{References}

1. Techfunnel. (2018). Latest Technology News and Trends in IT, Finance, HR, and Marketing

2. G. T. Waghmare, 2012). E-commerce; A Business Review and Future Prospects in Indian Business.

3. Chaffey, D. (2002). "Achieving marketing objectives through use of electronic communications technology."

4. Chaffey, D., \& Smith, P. (2008). Emarketing Excellence: planning and optimizing your digital marketing. Routledge

5. Giese, J. L. and J. A. Gote,(2000). Defining Consumer Satisfaction,. Academy of Marketing Science Review.

6. Digital marketing strategy advice - Smart Insights Digital Marketing.

7. Nibusinessinfo.co.uk. (2018, September 03). Retrieved from https://www.nibusinessinfo.co.uk 